\title{
Н.О. ОЛЕКСІЙЧЕНКО ОЦІНЮВАННЯ СУЧАСНОГО СТАНУ ДЕНДРОПАРКІВ УКРАЇНСЬКОГО ПОЛІССЯ МІСЦЕВОГО ЗНАЧЕННЯ
}

Наведено результати ретроспективного аналізу дендропарків місцевого значення («Гладковицький», «Еліта», «Пілява», «Юннатський»), які розташовані на території Українського Полісся. Проаналізовано зміни їх таксономічного складу насаджень в історичному аспекті та виявлено тенденцію до їхнього зменшення під впливом комплексної дії абіотичних $i$ біотичних факторів. Здійснено комплексне оцінювання сучасного стану дендропарків. Виявлено, що найбільшу дендрологічну цінність має дендропарк «Юннатський», у якому зростає 150 видів і культиварів деревних рослин; дендропарки «Еліта», «Пілява» та «Гладковицький» хоча і мають меншу цінність, однак в них зростають вікові насадження, інтродуковані та раритетні види. Запропоновано напрями раціонального використання дослідних дендропарків: науково-дослідний, навчальний та рекреаційний.

Ключові слова: дендропарки місцевого значення, Українське Полісся, таксономічний склад, інтродукція, дендрологічна цінність

Вступ. В умовах глобального потепління територія Українського Полісся належить до одного із критичних природно-географічних регіонів, у зв’язку з чим у 2011 р. було розпочато важливий природоохоронний проект «Включення питань змін клімату в управління вразливими екосистемами: природно-заповідні території Полісся, Україна» [3].

Важливу роль у вирішенні проблем як охорони біорізноманіття, так і інтродукції та раціонального збагачення видового різноманіття деревних рослин в Україні відіграють дендрологічні парки разом із ботанічними садами, парками-пам’ятками садово-паркового мистецтва. На території Українського Полісся станом на 01.01.2015 р. із 58 дендропарків України розташована найменша кількість (шість) дендропарків: «Гладковицький», «Еліта», «Пілява»

\footnotetext{
ОЛЕКСІЙЧЕНКО Надія Олександрівна - академік Лісівничої академії наук України, доктор сільськогосподарських наук, професор кафедри ландшафтної архітектури і садово-паркового будівництва Національного університету біоресурсів і природокористування України. м. Київ, Україна. Тел.: 098-330-22-78. E-mail: noolex@bigmir.net

${ }^{2}$ ПОдольХОВА Маріанна Олександрівна - аспірант кафедри ландшафтної архітектури і садово-паркового будівництва Національного університету біоресурсів і природокористування України. м. Київ, Україна. Тел.: 095-883-28-21. E-mail: mar grich@ukr.net
} 
(Житомирська область), «Юннатський» , «Сирецький дендропарк» (м. Київ) та «Дендрологічний парк Березнівського лісового коледжу» (Рівненська область) [2]. На думку О.М. Байрак, доцільно здійснювати комплексний моніторинг насаджень дендропарків, зокрема місцевого значення, оскільки більшість 3 них, зокрема в зоні Українського Полісся, досі досліджено недостатньо [1]. Оскільки нині вже розроблено методику щодо комплексного оцінювання сучасного стану парків-пам'яток садово-паркового мистецтва дендрологічної цінності [6], то її доцільно використовувати і для оцінювання сучасного стану дендропарків.

Мета роботи - визначити дендрологічну цінність дендропарків місцевого значення Українського Полісся на основі комплексного оцінювання їх сучасного стану.

Об’єкти та методика. Об'єктами досліджень були дендропарки «Гладковицький», «Еліта», «Пілява» та «Юннатський». Предметом досліджень був їх сучасний стан i динаміка таксономічного складу насаджень. Періодизацію створення та категорію цінності об’єктів досліджень визначали за критеріями комплексного оцінювання сучасного стану парків-пам'яток дендрологічної цінності Н.О. Олексійченко та Н.В. Гатальської [6]. Матеріалами для дослідження слугували письмові та картографічні матеріали. Видовий склад насаджень визначали під час польових обстежень та на основі інвентаризаційних і таксаційних матеріалів лісництв. Таксономічний аналіз проводили за міжнародним списком «The plant list» [9], санітарний стан насаджень визначали за інструкцією з технічної інвентаризації насаджень [5].

Обговорення та результати. За результатами аналізу структури дендропарків Українського Полісся, дендропарки «Гладковицький», «Еліта», «Пілява» та «Юннатський» є об’єктами природно-заповідного фонду місцевого значення [4]. Більшість 3 них розташована в Житомирській області («Гладковицький», «Еліта», «Пілява»), а дендропарк «Юннатський» - в Подільському районі м. Києва (табл.). 
Таблиця

Загальна характеристика дендропарків місцевого значення Українського Полісся

\begin{tabular}{|c|c|c|c|c|c|}
\hline $\begin{array}{c}\text { Назва } \\
\text { дендропарку }\end{array}$ & $\begin{array}{c}\text { Рік } \\
\text { створе } \\
\text { ння }\end{array}$ & $\begin{array}{c}\text { Рік } \\
\text { затверд- } \\
\text { ження } \\
\text { заповідно- } \\
\text { го статусу }\end{array}$ & $\begin{array}{c}\text { Адміністра- } \\
\text { тивне } \\
\text { розміщення } \\
\text { (область) }\end{array}$ & $\begin{array}{c}\text { Пло- } \\
\text { ща, } \\
\text { га }\end{array}$ & $\begin{array}{c}\text { Загальна } \\
\text { кількість } \\
\text { видів та } \\
\text { культиварів, } \\
\text { шт. }\end{array}$ \\
\hline «Пілява» & $\begin{array}{c}\text { друга } \\
\text { пол. } \\
\text { ХІХ } \\
\text { ст. }\end{array}$ & 1967 & Житомирська & 6,1 & 53 \\
\hline «Гладковицький» & 1957 & 1964 & Житомирська & 4,0 & 66 \\
\hline «Юннатський» & $\begin{array}{c}50-т і \\
\text { роки }\end{array}$ & 2006 & м. Київ & 13,7 & 150 \\
\hline «Еліта» & 1984 & 1988 & Житомирська & 4,8 & 112 \\
\hline
\end{tabular}

У процесі ретроспективного аналізу створення та розвитку дослідних об’єктів на основі аналізу літературних джерел виявлено, що найстарішим є дендропарк «Пілява», закладений у другій половині XIX ст., який, окрім того, раніше за всіх набув заповідного статусу (1967р.). Наймолодшим дендропарком $€$ дендропарк «Еліта», закладений у 1984 р., однак найпізніше отримав заповідний статус дендропарк «Юннатський» Національного екологонатуралістичного центру учнівської молоді України (далі - НЕНЦ) - у 2006 році.

Таким чином, більшість дендропарків було закладено упродовж п’ятого періоду створення (від середини XX ст. до 1991 р.), один - у третьому (від середини XIX ст. до 1917 р.) [6], а заповідний статус більшість дендропарків отримали в другій половині XX століття.

Аналізуючи розподіл дендропарків за площею, можна зробити висновок, що всі досліджені дендропарки, згідно з класифікацією, є малими: найменшим є дендропарк «Гладковицький» (4,0 га), а найбільшим - дендропарк «Юннатський» $(13,7$ га). 
Щодо таксономічного складу насаджень дослідних парків, то за результатами літературних джерел встановлено, що колекції дендропарків місцевого значення Українського Полісся нараховували від 73 до 300 видів та культиварів деревних рослин. Однак за результатами польових досліджень встановлено, що зазначений кількісний склад дендроколекцій дослідних парків значно відрізняється від фактичного, який представлений на сучасному етапі їх розвитку. Так, у дендропарку «Пілява» в 1968 р. налічувалося 75 таксонів на рівні виду, серед яких було багато культиварів кущових рослин, з яких нині залишилися лише два (Berberis thunbergii 'Atropurpurea' та Sambucus racemosa 'Plumosa'). Загалом нині у ньому зростає 53 види та культивари. У дендропарку «Гладковицький» в 1966 р. зростало 89 видів і культиварів деревних рослин, у 1970 р. їх кількість зменшилася до 73, а нині виявлено 66 таксонів на рівні виду. У дендропарку «Еліта», згідно з літературними даними, у 1988 р. росло 300 таксонів на рівні виду деревних рослин, з яких 250 - були інтродукованими для зони Полісся, а нині в ньому виявлено лише 112 види та культивари деревних рослин [7]. У дендропарку «Юннатський» нині виявлено близько 150 видів і культиварів деревних рослин, тоді як, згідно з літературними даними 2009 р., кількість таксонів становила 200 [2]. Варто зауважити, що до кількісного складу колекції власне дендропарку не було включено сорти плодового саду Національного еколого-натуралістичного центру учнівської молоді України, кількість яких становить близько 720 сортів.

Таким чином, за результатами ретроспективного аналізу та польових досліджень дослідних парків можна зробити висновок про тенденцію до зменшення таксономічного складу насаджень упродовж їх розвитку внаслідок комплексної дії абіотичних та біотичних факторів, зокрема антропогенних. Однією із вище зазначених проблем дендропарків $є$ особливості їх розвитку: дендропарки створили одні установи чи з ініціативи зацікавлених осіб, а за їх підтримання як впродовж функціонування, так і дотепер відповідають інші («Гладковицький», «Еліта»). 
Оскільки заповідний статус було надано досить давно більшості дендропарків, а у процесі їх розвитку відбулися значні зміни, то варто оцінити рівень їх дендрологічної цінності на сучасному етапі розвитку 3 метою визначення можливих напрямів їх раціонального використання.

Для цього доцільним $є$ використання методики комплексного оцінювання сучасного стану парків-пам'яток садово-паркового мистецтва дендрологічної цінності [6], згідно з якою виділено 11 критеріїв оцінки, а саме: 1) наявність письмової інформації щодо історії створення та розвитку об’єкта; 2) таксономічний склад колекцій; 3) наявність раритетних видів і багатовікових дерев; 4) принципи формування колекцій; 5) відповідність розміщення рослин на території парку згідно з їх біологічними та екологічними особливостями; 6) вікова структура насаджень; 7) зимостійкість насаджень; 8) посухостійкість насаджень; 9) природне поновлення інтродуцентів; 10) декоративність; 11) особливості догляду.

На основі аналізу історичних та архівних матеріалів дослідних об’єктів можна здійснити оцінку за першим критерієм. Так, найбільш повною $є$ інформація щодо дендропарку «Юннатський» та «Еліта» (4 бали), яку отримано із письмових матеріалів та спогадів працівників щодо етапів формування колекцій та основного видового складу, принципів формування колекцій та інвентаризаційні відомості [2]; із архівних картографічних та іконографічних матеріалів. Найменше інформації щодо дендропарків «Гладковицький» та «Еліта» (3 бали), оскільки схема посадок виявилася незавершеною на етапі їх закладання. Найменший бал отримав дендропарк «Пілява» (2 бали), оскільки щодо нього немає повноцінних інвентаризаційних даних впродовж його розвитку.

Найважливішим критерієм оцінювання дендрологічної цінності парків $є$ кількість видів і внутрішньовидових одиниць (підвидів, різновидів, культиварів, гібридів), які представлені у насадженнях дендропарків. 3 метою оцінки таксономічного складу дослідних об’єктів використано інвентаризаційні матеріали різних етапів їх розвитку: під час створення об’єктів 
(«Гладковицький», «Еліта»), обгрунтування заповідання («Пілява»), реконструкції та сучасних досліджень («Юннатський»), які уточнено в процесі власних польових пошуків.

Таким чином, найбільша колекція представлена у дендропарку «Юннатський» (150 таксонів на рівні виду), тому оцінка за другим критерієм $є$ найвищою - 4 бали. Дещо менша кількість зосереджена на території дендропарку «Еліта» (112 таксонів на рівні виду), серед яких виявлено значну частку (близько 70\%) інтродуцентів для Житомирського Полісся. Колекції дендропарків «Пілява» та «Гладковицький» представлені 66 та 53 таксонами на рівні виду, тому оцінка за цим критерієм для них становить 3 бали.

Окрім того, для зручності та наочності порівняння видового різноманіття різних дендрологічних парків можна застосувати відносний показник насиченості видового різноманіття в межах конкретної території. Його можна визначити як відношення кількості видів та внутрішньовидових таксонів до площі, на якій вони представлені. Так, для дендропарку «Еліта» цей показник $є$ найвищим (62), значно меншим $є$ показники для дендропарків «Гладковицький» $(16,5)$, а для дендропарків «Юннатський» та «Пілява» показники насиченості видового різноманіття є ще меншими - 10,3 та 8,7 відповідно. Це зумовлено насамперед тим, що значну частку території цих дендропарків займають природні насадження із аборигенних видів (Аcer platanoides L., Quercus robur L., Pinus sylvestris L. та ін.), а також малоцінні насадження з інтродукованих видів (Robinia pseudoacacia L.).

Серед насаджень дослідних об’єктів, на основі аналізу літературних даних та натурних обстежень, виявлено вікові деревні рослини, а у процесі аутсозологічного аналізу їх видового складу - раритетні види, які занесено до різних офіційних охоронних списків. Так, на території дендропарку «Пілява» кількість раритетних видів є найменшою (4 види), однак у ньому наявні вікові насадження господарсько-цінних видів (Larix decidua Mill., Picea abies (L.) Karst., Fagus sylvatica L. та ін.) віком близько 115 років (рис. 1), тому оцінка за третім критерієм становить 4 бали. У дендропарку «Еліта» зростає 13 
раритетних видів та вікові екземпляри Tilia cordata Mill., а в дендропарку «Юннатський» найбільша кількість (20) раритетів та екземпляри вікових насаджеь Tilia cordata Mill. (див. рис. 1) та Ouercus robur L. Відповідно оцінка за цим критерієм для цих об’єктів становить 3 бали. У дендропарку «Гладковицький» виявлено 16 раритетних видів, вікових дерев у ньому немає, тому оцінка $€$ найнижчою (2 бали).
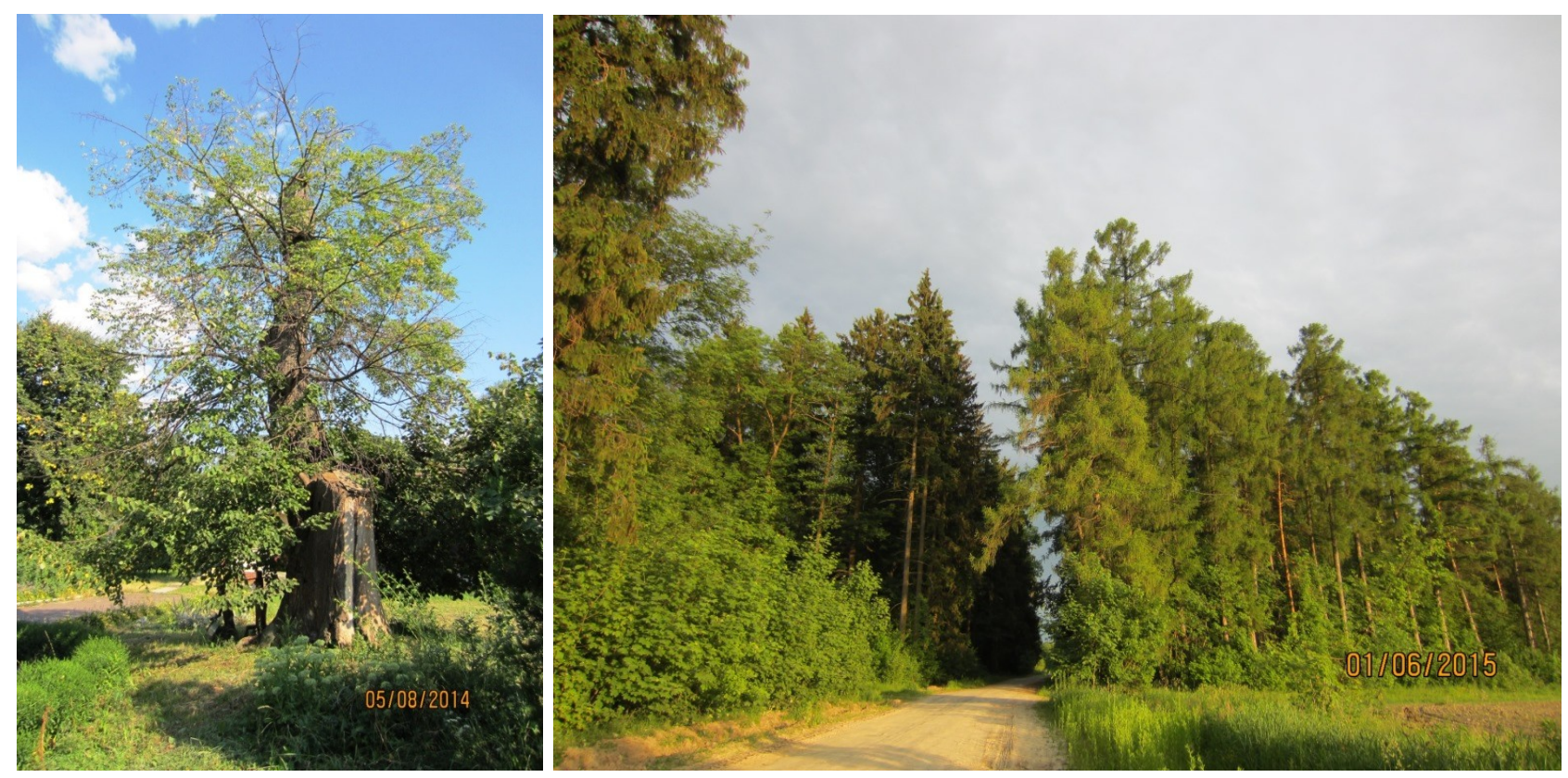

Рис. 1. Віковий екземпляр Tilia cordata Mill. дендропарку «Юннатський» (ліворуч) та куртина із Larix decidua Mill. дендропарку «Пілява» (праворуч)

Варто зауважити, з огляду на історичний аспект, що насадження у дендропарках створювалися за систематичним, екологічним та декоративним принципами формування деревних колекцій. Так, у дендропарку «Юннатський» використано всі три принципи, однак в деяких посадках деякі з них порушені, тому відповідно оцінка за четвертим критерієм становить 4 бали. У дендропарку «Еліта» (рис. 2) переважно використано декоративний принцип планування колекцій, однак на сучасному етапі розвитку внаслідок біотичних та абіотичних факторів значна частка насаджень втратила свою декоративність у зв’язку із задовільним станом, тому колекція цього об'єкта може бути оцінена у 3 бали.

У дендропарках «Гладковицький» (рис. 3) та «Пілява» нині залишилася незначна частка куртин (близько 20\%), створена із урахуванням систематичного 
та фізіономічного принципів, тому відповідно оцінка за цим критерієм для згаданих об’єктів може становити 2 та 1 бали.

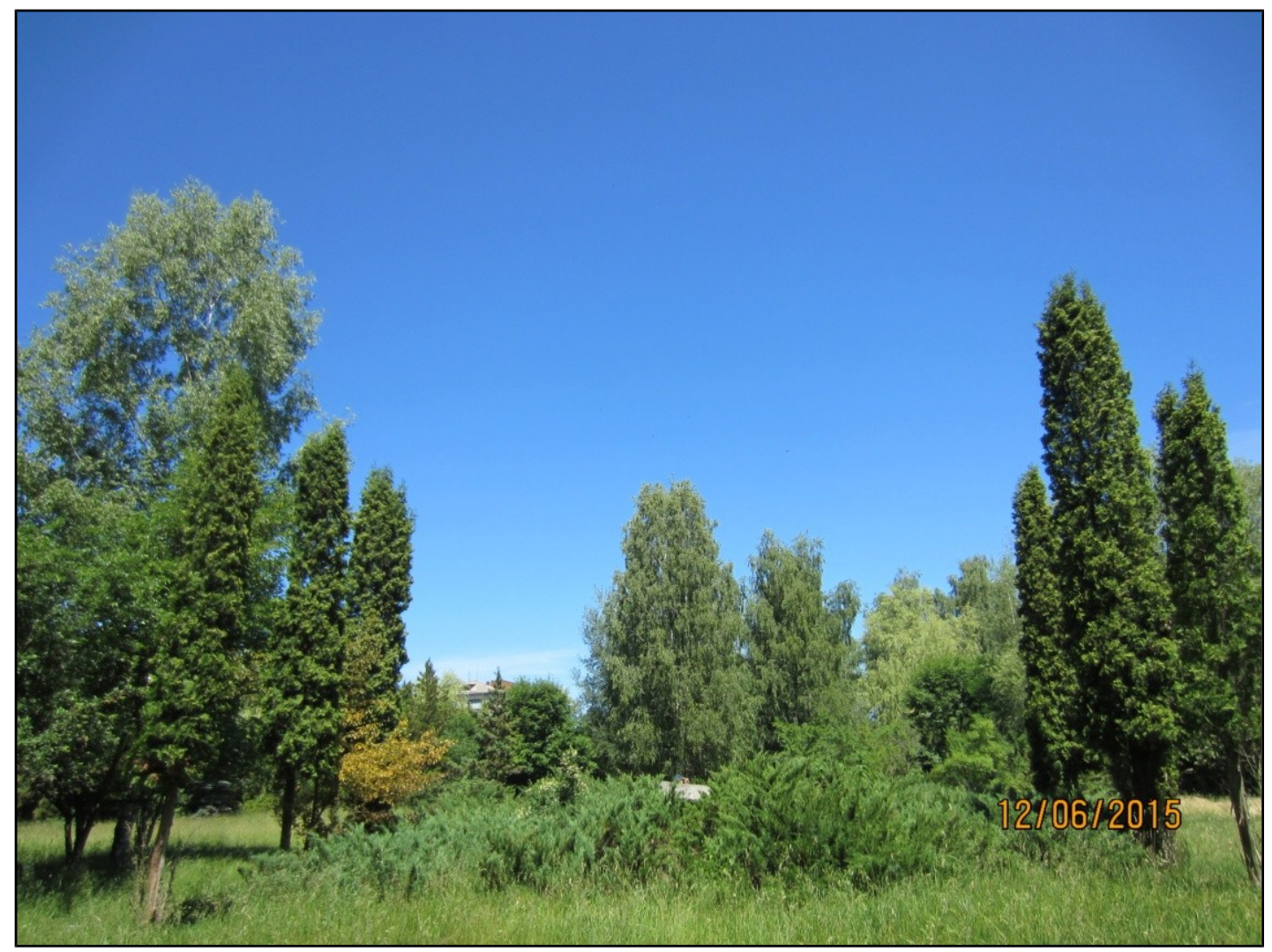

Рис. 2. Центральна ландшафтна композиція дендропарку «Еліта»

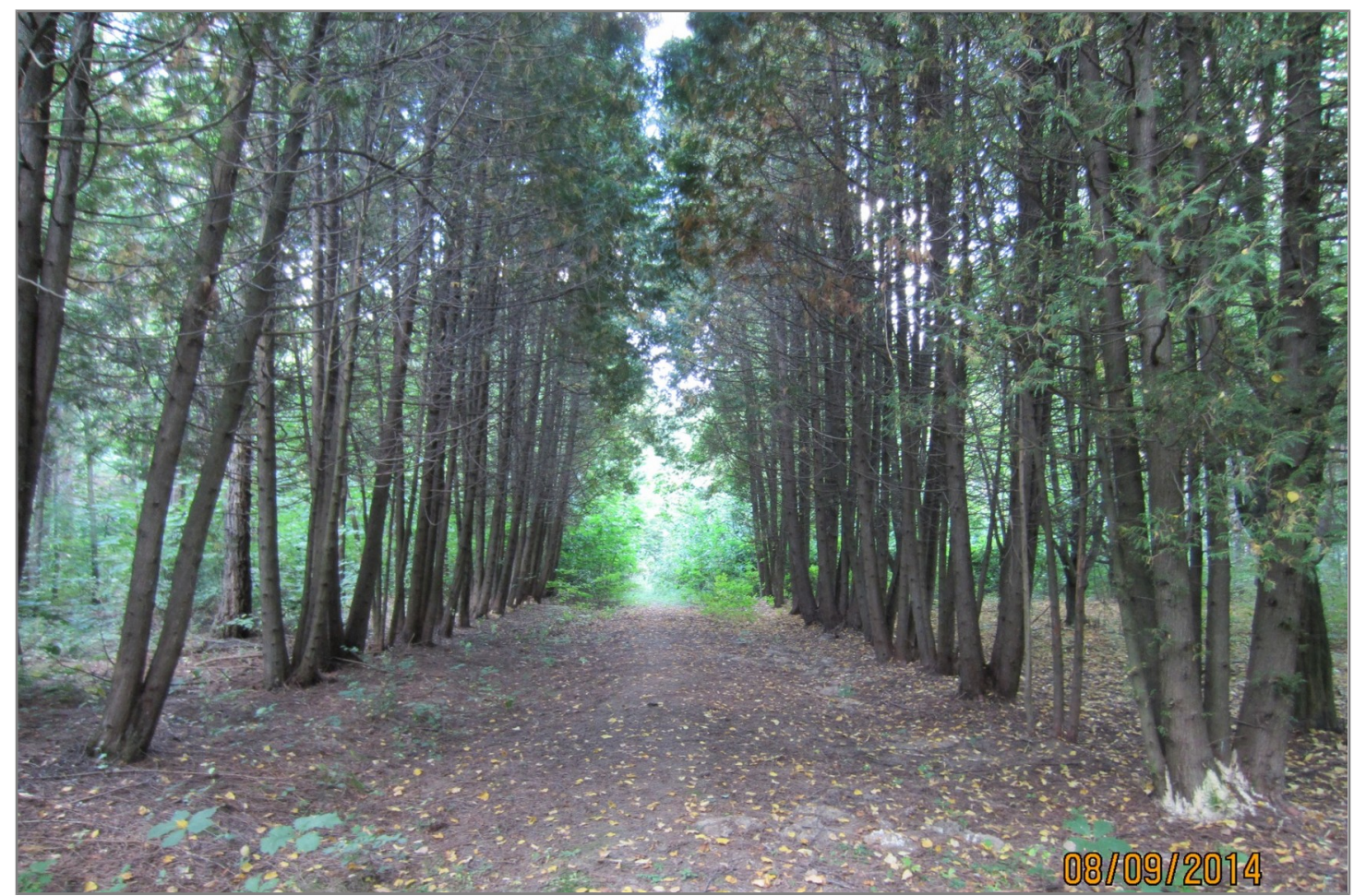

Рис. 3. Головна алея дендропарку «Гладковицький» із Thuja occidentalis L. 
Важливим критерієм для встановлення дендрологічної цінності парків $€$ відповідність розміщення рослин на території парку згідно з їх біологічними та екологічними особливостями, оскільки це, безумовно, впливає на ріст i розвиток рослин, та, головним чином, на успішність адаптації інтродуцентів. Вивчаючи умови зростання рослин у дендропарку «Юннатський», можна зробити висновок, що більшість колекцій рослин було створено з урахуванням екологічних вимог рослин, однак на сучасному етапі розвитку дуже часто молоді посадки здійснюють під наметом дерев в умовах значного затінення (4 бали). Щодо дотримання екологічних вимог рослин у дендропарку «Еліта», то можна стверджувати, що через недотримання відстаней між деревами під час створення куртин та внаслідок несистематичного догляду значна частка (понад 50\%) особин колекційного фонду перебуває в умовах загущеності, тому оцінка становить 3 бали. У дендропарках «Гладковицький» та «Пілява» рослини в колекціях було розміщенно частково з урахуванням їх екологічних вимог, однак упродовж їх існування умови зростання зазнали значних змін внаслідок дії комплексу факторів (сильних вітрів, посухи, поширення експансивних видів та ін.). Тому оцінка за цим критерієм для таких парків становить 2 бали.

Якщо оцінювати вікову структуру насаджень дослідних об’єктів, то можна зробити висновок, що майже всі види та культивари, представлені у їх колекціях, досягли фази генеративного розвитку, тому відповідно оцінка за цим критерієм становить 5 балів.

Якісний стан колекційних насаджень дендропарків значною мірою залежить від таких особливостей деревних рослин, як посухостійкість та зимостійкість. Таким чином, якщо оцінювати зимостійкість представників колекційного фонду дослідних об’єктів, то можна зробити висновок, що переважна більшість (понад 80\% видів) є зимостійкими. Щодо оцінювання посухостійкості, то більшість насаджень у згаданих парках не страждає від посухи. Тому оцінка за обома критеріями для всіх парків є найвищою (5 балів).

Аналізуючи здатність до природного поновлення деревних видів на території дослідних об’єктів, можна стверджувати на основі польових 
обстежень, що найбільше інтродукованих видів (13) утворюють самосів у дендропарку «Гладковицький» (Quercus rubra L., Pinus strobus L., Thuja occidentalis L., Castanea sativa Mill. та ін.). Відповідно оцінка за дев’ятим критерієм для цього об’єкта становить 1 бал. У дендропарках «Пілява», «Юннатський» та «Еліта» поновлення відсутнє у більшості інтродукованих видів деревних рослин, тому оцінка за цим критерієм відсутня.

Десятим критерієм оцінювання дендрологічної цінності $€$ декоративність насаджень, яку рекомендовано оцінювати за методикою О.Г. Хороших та О.В. Хороших [8]. Однак, на нашу думку, визначення таким чином є трудомістким та не дуже доцільним, по-перше, з огляду на функціональне призначення дендропарків. По-друге, декоративність екземпляра окремо взятого виду значною мірою залежить від сукупності умов його місцезростання, які впливають на його санітарний стан i, як наслідок, декоративність на сучасному етапі розвитку об’єкта. Тому з метою оцінювання санітарного стану насаджень було використано «Інструкцію з технічної інвентаризації насаджень» [5], а вище згадану методику, на нашу думку, доцільніше застосовувати для оцінювання перспективності використання насаджень дослідних об’єктів як маточників 3 метою розмноження високодекоративних видів і культиварів.

Таким чином, аналізуючи санітарний стан колекцій дослідних об’єктів, за часткою деревних видів, стан яких можна оцінити як добрий, більшість дендропарків за цим критерієм можна оцінити в 1 бал, оскільки лише 11-20\% видів перебувають у доброму стані, тоді як дендропарк «Юннатський» - в 2 бали, у якому ця частка становить близько 25\%. Візуальні спостереження показали, що переважна частка видів усіх дендроколекцій перебуває у задовільному стані з різних причин: наявність всохлих гілок у кроні, їі розрідженість та нерівномірний розвиток, ушкодження кори та наявність дупел у стовбурі дерев, а також пошкодження шкідниками та ураження хворобами та омелою. Ці негативні процеси найчастіше спричинені загущеністю посадок внаслідок несистематичного догляду за ними, а також біологічним старінням кущових видів, поширенням інвазійних та експансивних видів тощо. 
Варто зауважити, що останні два критерії нерозривно пов’язані 3 особливостями догляду за насадженнями та територією об’єктів, а саме, періодичністю та якістю догляду, які, своєю чергою, залежать від підпорядкування дендропарків. За цим критерієм найбільшу оцінку (5 балів) має дендропарк «Юннатський» Національного еколого-натуралістичного центру учнівської молоді України (рис. 4), в якому впродовж розвитку проводили роботи з догляду та реконструкції насаджень.

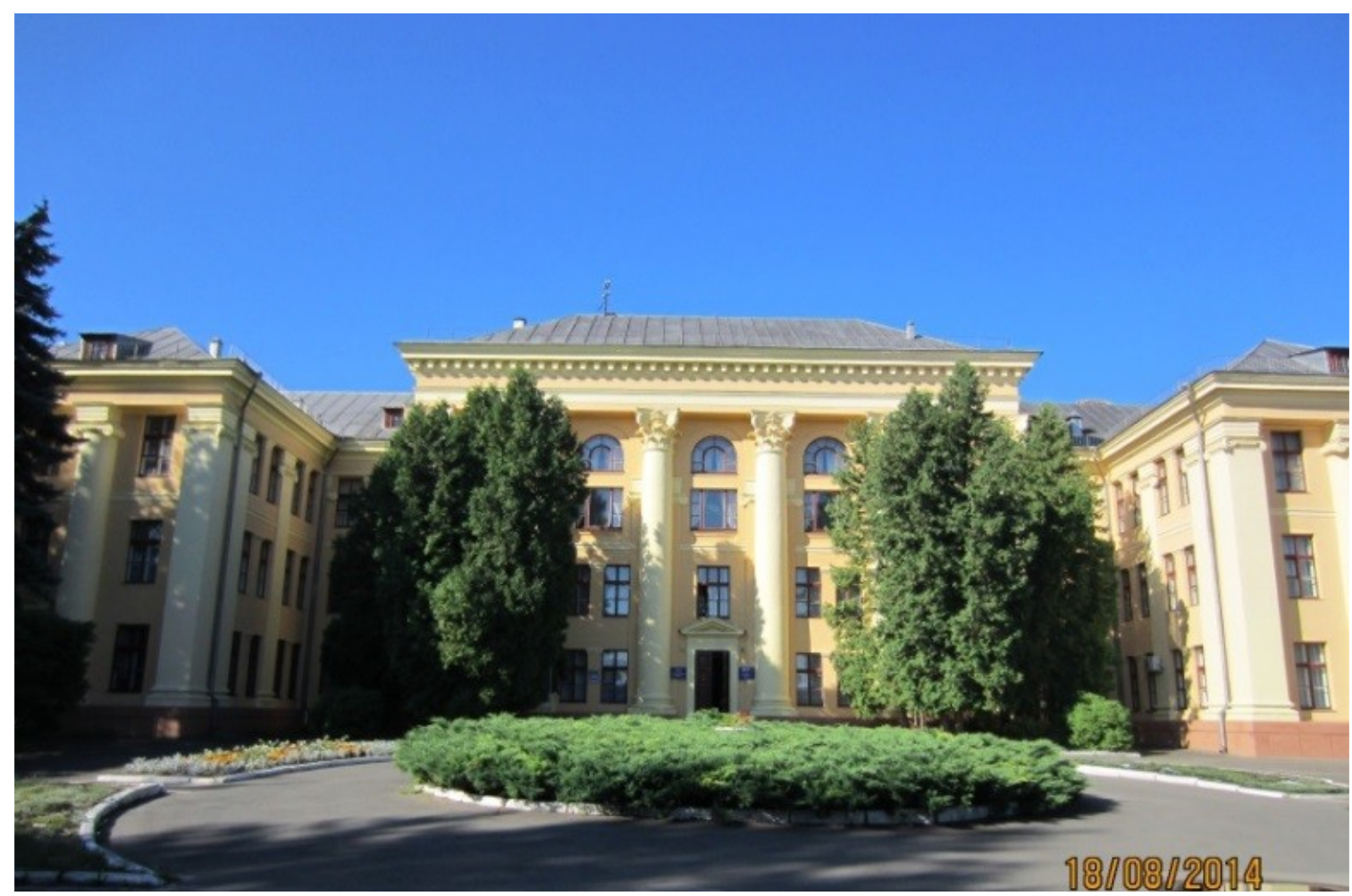

Рис. 4. Вхід до дендропарку «Юннатський» Національного екологонатуралістичного центру учнівської молоді України

У дендропарку «Пілява» та «Гладковицький», які належать лісництвам, роботи з догляду за насадженнями проводили несистематично, тому залежно від часу останнього догляду оцінити їх за цим критерієм можна в 4 та 3 бали. Догляд за дендропарком «Еліта», який належить дослідному господарству «Грозинське» інституту сільського господарства «Полісся», був систематичним лише впродовж перших років після його закладання, тому оцінка за згаданим критерієм є найнижчою (1 бал). 
Таким чином, за результатами проведених комплексних досліджень, отримано числові результати, які для зручності порівняння подано у вигляді діаграми (рис. 5).

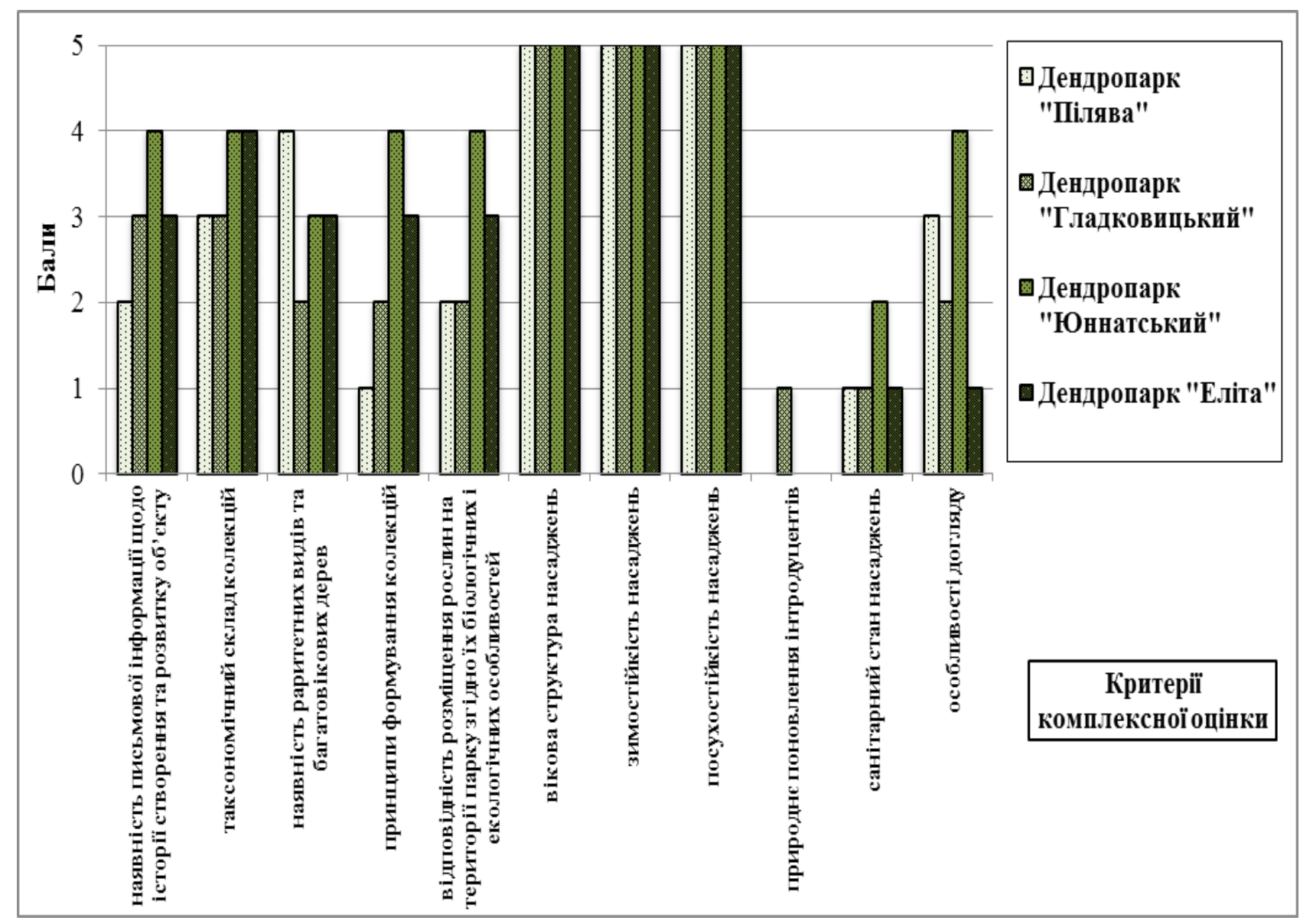

Рис. 5. Результати комплексного оцінювання дендропарків місцевого значення Українського Полісся

За підсумками здійсненого оцінювання можна визначити категорію дендрологічної цінності дослідних об’єктів. Таким чином, усі досліджувані дендропарки мають дендрологічну цінність, однак більшість з них належать до категорії малоцінних на сучасному етапі розвитку. Найбільшу цінність має дендропарк «Юннатський» (40 балів), у якому представлена найбільша колекція деревних рослин та найбільша кількість раритетних видів. Дещо меншу цінність має дендропарк «Еліта» (34 бали), у якому зростає багато інтродуцентів та наявні вікові дерева. За сумою показників дендропарки «Пілява» та «Гладковицький» отримали найнижчу оцінку - 31 бал, однак перший дендропарк вирізняється переважанням вікових насаджень господарсько-цінних видів, а другий - значною часткою раритетних видів та 
великою кількістю природного поновлення як інтродуцентів, так і аборигенних видів.

Враховуючи дендрологічну цінність дослідних парків, можна запропонувати основні напрями їх раціонального використання. Так, на базі дендропарків «Пілява» та «Гладковицький» доцільним, передусім, є вивчення акліматизації деревних господарсько-цінних видів та використання перспективних інтродуцентів як вихідного селекційного матеріалу. Дендропарки «Юннатський», «Еліта» та «Пілява», окрім виконання вище зазначених функцій, можуть відігравати роль навчальної бази. Варто зауважити, що всі дендропарки можуть також успішно виконувати рекреаційну функцію. Однак для досягнення цієї мети потрібним і доцільним є підвищення рівня охоронних заходів та благоустрою, проведення часткової реконструкції насаджень з урахуванням особливостей їх функціонального призначення.

Висновки. Серед дендропарків Українського Полісся більшість $\epsilon$ дендропарками місцевого значення («Гладковицький», «Еліта», «Пілява», «Юннатський»). Більшість дендропарків було закладено та надано їм заповідний статус у другій половині ХХ ст. Упродовж їх розвитку відбувалося зменшення таксономічного складу насаджень у зв’язку із комплексною дією абіотичних та біотичних факторів.

За результатами комплексного оцінювання сучасного стану, всі досліджувані дендропарки мають дендрологічну цінність, однак більшість з них належать до категорії малоцінних («Еліта», «Пілява» та «Гладковицький»). Найбільшу дендрологічну цінність має дендропарк «Юннатський». У колекціях дослідних парків представлені вікові насадження, значна кількість інтродукованих та раритетних деревних видів. Більшість насаджень дослідних парків перебуває у задовільному стані, однак, незважаючи на це, на сучасному етапі розвитку вони мають значний науково-дослідний та рекреаційний потенціал, а тому виникає потреба та доцільність розроблення рекомендацій щодо заходів їх збереження та популяризації. 


\section{СПИСОК ВИКОРИСТАНИХ ДЖЕРЕЛ}

1. Байрак О.М. Дендропарки як об’єкти природно-заповідного фонду України / Матеріали IV Міжнар. наук. конф., присвяч. 225-річчю дендрологічного парку «Олександрія» «Збереження та реконструкція ботанічних садів і дендропарків в умовах сталого розвитку» [23-26 вересня 2013 р.] // О.М. Байрак. - Біла Церква, 2013. - Ч.1. - С. 10-11.

2. Ботанічні сади та дендропарки / Державна служба заповідної справи Мінприроди України, Глобальний екологічний фонд, Програма розвитку ООН в Україні; [відп. ред.: Т.М. Черевченко, С.С. Волков ; упоряд. : В.В. Кваша, О.О. Семенова, Н.В. Чувікіна]. - К. : ТОВ "Майстерня книги", 2009. - 296 с.

3. Включення питань змін клімату в управління вразливими екосистемами [Електронний ресурс]. - 2015. - 1 с. Режим доступу: http://wetlandsclimate.net/index.php?

PHPSESSID=f7f1a4d127e27eeda2c133625eeb1dd6\&codelang=ua

4. Гричук М.О. Ретроспективний аналіз створення та розвитку дендропарків Українського Полісся / М.О. Гричук // Наук. вісник Нац. ун-ту біоресурсів і природокористування України. Серія «Лісівництво та декоративне садівництво». - 2014. - Вип. 198. - Ч.1. - С. 152-159.

5. Інструкція з технічної інвентаризації зелених насаджень у населених пунктах України [Електронний ресурс]. - Режим доступу: http://search.ligazakon.ua/__doc2.nsf/link1/REG6470.html

6. Олексійченко Н.О. Парки-пам'ятки садово-паркового мистецтва Центрально-Придніпровської височинної області: моногр. / Н.О. Олексійченко, Н.В. Гатальська. - К.: ЦП «КОМПРИНТ», 2012. - Ч.1 - 145 с.

7. Олексійченко Н.О. Таксономічний склад та систематична структура насаджень дендропарків Житомирського Полісся / Н.О. Олексійченко, М.О. Гричук // Науковий вісник Нац. лісотехн. ун-ту України : зб. наук.-тех. праць. - 2011. - Вип. 24.11. - С. 8-14.

8. Хороших О.Г. Шкала комплексної оцінки декоративних ознак деревних рослин / О.Г. Хороших, О.В. Хороших //Наук. вісник Укр. держ. лісотех. ун-ту України «Дослідження, охорона та збагачення біорізноманіття» : зб. наук.-техн. праць. - 1999. - Вип. 9.9. - С. 167-170.

9. The plant list [Електронний ресурс].- Режим доступу: http://www.theplantlist.org

Н.О. Алексейченко, М.О. Подольхова

ОЦЕНКА СОВРЕМЕННОГО СОСТОЯНИЯ ДЕНДРОПАРКОВ УКРАИНСКОГО ПОЛЕСЬЯ МЕСТНОГО ЗНАЧЕНИЯ 
Важную роль в решении проблем охраны биоразнообразия, интродукции и рационального обогащения видового разнообразия древесных растений в Украине играют дендрологические парки. Актуальным является исследование дендропарков местного значения, поскольку они мало исследованы, особенно в зоне Украинского Полесья как одного из критических регионов в условиях глобального потепления.

Объектами исследований были дендропарки местного значения: «Гладковицкий», «Элита», «Пилява» и «Юннатский». Периодизация создания и категория ценности объектов исследований определены по методике комплексной оценки современного состояния парков-памятников дендрологической ценности Н.А. Алексейченко и Н.В. Гатальской.

По результатам исследований, в частности, по итогам оценок по 11 критериям современного состояния, определена категория дендрологической ценности исследуемых объектов. Наибольшую ценность представляет дендропарк «Юннатский» (40 баллов), в котором представлена самая большая коллекция (150 видов и культиваров) древесных растений и большое количество раритетных видов (20). Несколько меньшую ценность имеет дендропарк «Элита» (34 балла), в котором растет много интродуцентов и имеются вековые деревья. По сумме показателей дендропарки «Пилява» и «Гладковицкий» получили самую низкую оценку - 31 балл, однако первый дендропарк отличается преобладанием возрастных насаждений хозяйственно-ценных видов, а второй - значительной долей (40\%) раритетных видов и большим количеством естественного обновления 13 интродуцентов.

Учитывая дендрологическую ценность исследуемых парков, предложены основные направления их рационального использования. На базе дендропарков «Пилява» и «Гладковицкий» целесообразным, прежде всего, является изучение акклиматизации древесных хозяйственно-ценных видов и использования перспективных интродуцентов в качестве исходного селекционного материала. Дендропарки «Юннатский», «Элита» и «Пилява», кроме выполнения вышеупомянутых функций, могут служить учебной базой. Большинство насаждений исследованных парков находится в удовлетворительном состоянии, поэтому возникает необходимость и целесообразность разработки рекомендаций по мерам с целью сохранения и популяризации дендропарков.

Ключевые слова: дендропарки местного значения, Украинское Полесье, таксономический состав, интродукция, дендрологическая ценность

\section{N. Alekseychenko, M. Podolhova}




\section{ASSESSMENT OF PRESENT STATE OF DENDROLOGICAL PARKS OF LOCAL IMPORTANCE IN THE UKRAINIAN POLISSYA}

Dendrological parks play a significant role in solving the problems of the biodiversity protection, introduction and enrichment of tree species diversity in Ukraine. The local importance dendroparks studies are actual, because the dendroparks aren`t studied well enough, especially concerning the Ukrainian Polissya area, as it is one of the critical areas in the global warming conditions.

As the research objects of local importance dendroparks "Gladkovitsky", "Elita", "Pilyawa" and "Yunnatsky" were studied. Creation periodization and value category of the research objects were determined by the method developed by Alekseychenko N.A. and Gatalskaya N.V and involved the present state integrated assessment of the dendrological value parks-monuments.

According to the research, in particular, the present state assessments results basing on the 11 criterias, was defined the dendrological value category of the objects. Dendrological park "Yunnatsky" (40 points) has the most value, because it presents the largest collection (150 species and cultivars) of woody plants and a large number of rare species (20). Dendrological park "Elita" (34 points) has a little bit smaller value, a lot of exotic species and centuries-old trees grow in its territory. The dendrological parks "Pilyawa" and "Gladkovitsky" received the lowest score - 31 points according to the sum of the numbers, but the first dendropark has age plantations of commercially valuable species, and the second - a significant share (40\%) of rare species and plenty of natural upgrade of 13 exotic species.

Taking into account the dendrological parks value the basic directions of their rational using proposed. First of all, on the basis of dendroparks like "Pilyawa" and "Gladkovitsky", it's rational to study the economical valuable wood species acclimatization as well as to use the exotic species as a promising source of breeding material. Dendroparks "Yunnatsky", "Elita" and "Pilyawa" can serve as a training base in addition to the above mentioned functions.

Most of the researched parks plantations are in a satisfactory condition, so it's necessary and rational to work out the recommendations aiming to preserve and popularize the dendrological parks.

Key words: dendroparks of local impotance, Ukrainian Polissya, taxonomic composition, introduction, dendrological value 